\title{
DROUGHT AND SALT STRESS INDUCED ANATOMICAL CHANGES IN LEAVES AND STEMS OF INDIAN BORAGE PLANTS (PLECTRANTHUS AMBOINICUS, LOUREIRO SPRENGEL)
}

\author{
G.S.A. Eisa \\ Agric. Bot. Dept., Fac. Agric., Zagazig Univ., Egypt
}

Received: Nov. 3, 2016

Accepted: Nov. 28,2016

\begin{abstract}
Two pot experiments were conducted during 2014 and 2015 successive growing summer seasons to study the anatomical structure changes in leaves and stems of Indian borage plants (Plectranthus amboinicus Lour. Sprengel) due to exposure drought and salt stress. The anatomical analysis data showed that plants supplied with $65 \%$ of water holding capacity (WHC) showed considerable increase in both leaves and stems dimensions as compared to the other irrigation levels of water (45 and 25\% of WHC). In addition, the highest drought stress level (25\% of WHC) markedly decreased all tested parameters of both leaves and stems of Indian borage plant. As for the effect salinity on the anatomical structure of the leaf blade through the midrib region as well as lamina indicated that increasing salinity level decreased anatomical dimensions of midrib region (midrib thickness), dimensions of the midvein bundle (length, width, number of xylem vessels and average diameter of xylem vessel) and dimensions of the lamina (lamina thickness, palisade thickness and spongy tissue thickness). It was clear that the high level of salinity ECw (11.7 dSm-1) caused destroy almost the contents of vascular bundle in midrib region. The same trend was noticed on stem anatomical parameters and showed that increasing salinity level markedly reduced most of stem anatomical characters, i.e., diameter of the whole section, vascular cylinder thickness, fibers tissue thickness, phloem thickness, xylem thickness, average number of xylem vessel, average diameter of xylem vessel and pith diameter mean while thickness of cortex was increased. It was noticed that the high quantities xylem fibers in control plants was recorded and it decreased with low salinity level $E C w(3.9 \mathrm{dSm}-1)$, whereas, moderate and high salinity levels $E C w(7.8$ and $11.7 \mathrm{dSm}-1)$ led to absence xylem fibers.
\end{abstract}

Key words: Plectranthus amboinicus, Indian borage, drought and salt stress, leaves and stems structure.

\section{INTRODUCTION}

Plectranthus amboinicus Lour. Sprengel is one of the most documented species in family Lamiaceae. The genus Plectranthus includes more than 350 species. $P$. amboinicus, also commonly known as Indian borage, and is a fleshy, succulent herb famous for its distinct oregano-like flavor and odor. It is one of the most cited species especially for its medicinal properties, accounting for $68 \%$ of all customary applications of this genus (Lukhoba et al., 2006). Plectranthus amboinicus is an annual or perennial herbs or subshrubs which are often succulents with a tendency for climbing or creeping and propagated by stem cuttings. It can reach over $1 \mathrm{~m}$ in height and even more in width in the wild (Roshan et al., 2010). Plectranthus amboinicus is a medicine very commonly used in Unani, Ayurveda, Sidda, folk and other traditional practices of healthcare management (Swamy and Sinniah, 2015). In addition, Plectranthus amboinicus is a perennial herb occurs naturally throughout the tropics and warm regions of Africa, Asia and Australia. This herb has therapeutic and nutritional properties attributed to its natural phytochemical compounds which are highly valued in the pharmaceutical industry. Besides, it has horticultural properties due to its aromatic nature and essential oil 
producing capability. It is widely used in folk medicine to treat conditions like cold, asthma, constipation, headache, cough, fever and skin diseases. The leaves of the plant are often eaten raw or used as flavoring agents, or incorporated as ingredients in the preparation of traditional food. The literature survey revealed the occurrence 76 volatiles and 30 non-volatile compounds belonging to different classes of phytochemicals such as monoterpenoids, diterpenoids, triterpenoids, sesquiterpenoids, phenolics, flavonoids, esters, alcohols and aldehydes. Studies have cited numerous pharmacological properties including antimicrobial, antiinflammatory, antitumor, wound healing, anti-epileptic, larvicidal, antioxidant and analgesic activities (Greetha et al., 2016).

The most new lands in Egypt are subjected to water stress or salinity which are of the most serious environmental problems that cause osmotic stress and reduction in plant growth and crop productivity in irrigated areas of arid and semiarid regions (El-Banna et al., 2002). Abou-Bakr et al. (1998) on wheat, indicated that the increases in water stress by gradually increasing of irrigation intervals had a harmful effect on the anatomy of leaves were also affected; stomata chambers, thickness of the epidermal cells, sizes of the hinge cells, midrib diameter and the mean distance between the vascular bundles were decreased. Yang et al. (2007) indicated that under water stress condition, xylem vessel diameter decreased compared with control in winter wheat plants. Drought stress is one of the most serious world-wide problems for agriculture, (El-Tayeb and Naglaa, 2010) since it affects physiological process, and limits plant growth and crop productivity of wheat plant. Moderate or high salinity levels led to decrease the thickness of either midrib region or leaf blade (palisade and spongy parenchyma) as well as the main vascular bundle dimensions (Khafagy, et al., 2009). Salinity is one of most important factors limiting plant growth and delaying seed germination as well as final germination percentage (Rahman et al., 2000). Moreover, plant growth can beseverely affected by salt stress through inhibition of growth, decrease in photosynthetic activity, water deficit, ion uptake and salt-specific damages or oxidative stress (Zhu, 2001). Salt stress caused alterations in plant cell structure and functions, and induced morphological and anatomical changes (Mitsuya et al. 2000).

The present study aimed to test the anatomical structure changes in leaves and stems of Plectranthus amboinicus plant due to drought and salinity stress conditions.

\section{MATERIALS AND METHODS}

This work was divided in two parts as follows:

First part: effect of drought on anatomical characters of leaves and stems of Indian borage plants.

Second part: effect of water salinity on anatomical characters of leaves and stems of Indian borage plants.

Drought Stress Experiment: Two pot experiments were carried out during the spring seasons of 2014 and 2015 at Zifta district (private greenhouse), Gharbia Governorate, Egypt, in order to study the effect of drought stress on anatomical characters of leaves and stems of Indian borage plants. The stem cuttings were obtained from Horticulture Department, National Research Center, Giza, Egypt and planted on $4^{\text {th }}$ March in the two seasons. Three stem cuttings were planted in pots (30 $\mathrm{cm}$ in depth and $28 \mathrm{~cm}$ in diameter) filled with $8 \mathrm{~kg}$ air dried sandy loam soil.

Three treatments were applied in this experiment as follows: -

$65 \%$ of water holding capacity (WHC) where plants received adequate water and two levels of water stress as W1 (45\%) and W2 $(25 \%)$ of WHC 
All experimental pots received equal amounts of irrigation water for 15 days and drought treatments started at 15 days after planting. Irrigation water was added in the morning along plant life. The necessary moisture was maintained by means of daily correction. All pots received commercial fertilizer NPK (19-19-19), at a rate of $2 \mathrm{gm}$ per pot, each two weeks during the plant growing season. The treatments were arranged in a complete randomized design with three replicates each replicate contains two pots.

Salinity Stress Experiment: This experiment included four treatments of salinity levels resulted from sodium chloride were as follows: (1) Control (tap water, ECw $\left.0.7 \mathrm{dSm}^{-1}\right)$, (2) $\mathrm{ECw}\left(3.9 \mathrm{dSm}^{-1}\right)$, (3) $\mathrm{ECw}$ $\left(7.8 \mathrm{dSm}^{-1}\right)$ and (4) ECw $\left(11.7 \mathrm{dSm}^{-1}\right)$.

Sodium chloride $(\mathrm{NaCl})$ was obtanied from EL-Gomhoria Co., Egypt. All experimental pots irrigated by tap water for the first 15 days then salinity treatments was started at 15 days after planting. All agricultural practices were applied as mentioned in the first experiment. The treatments of this experiment was distributed in a randomized complete design with three replicates each replicate contains two pots with three stem cuttings in each one.

\section{Anatomical investigation:}

For anatomical studies, in both experiments, After 50 days from planting stems and leaves samples were randomly taken from each treatment for examination anatomy characters. Specimens of selected treatments of $P$. amboinicus Lour. Sprengel plant leaves and stems were taken through the second growing season 2015. Specimens were taken from the main stem at its median portion of upper fourth internode and its leaf blade from various treatments for examination the effect of irrigation water levels and water salinity on certain histological features for leaves and stems. These specimens were cut into pieces of $1.0 \mathrm{~cm}$ length, then killed and fixed for 24 hours at least in FAA as plant fixative solution (formalin acetic alcohol) represented by the following formula: $10 \mathrm{ml}$. formaldehyde (37- 40\%), $5 \mathrm{ml}$. glacial acetic acid, $50 \mathrm{ml}$. ethyl alcohol (95\%) and $35 \mathrm{ml}$. distilled water. Then the specimens were washed and dehydrated in ascending concentrations of ethyl alcohol series, after that it cleared in transferring concentrations of xylene and absolute alcohol. Specimens were embedded in pure paraffin wax of melting point $52-54{ }^{\circ} \mathrm{C}$. Sections were prepared using EPMA a rotary microtome at 14 microns $(\mu)$. Paraffin ribbons were mounted on slides and sections were stained in safranin and light green. Sections were mounted in Canada balsam (Willey 1971). Selected sections were examined to detect histological manifestations of the chosen treatments using light microscope (Olympus) with digital camera (Canon power shot S80) connected to computer; the photographs were taken by Zoom Browser Ex Program. The dimensions of leaves and stems blade sections were measured by using Corel Draw program ver.11

\section{RESULTS AND DISCUSSION Drought stress experiment: Leaf features:}

Data presented in Table (1) and showed in Fig. (1) reveal that $P$. amboinicus plants supplied with $65 \%$ of water holding capacity (WHC) considerably gave the highest values of leaf blade dimensions \{midrib thickness, dimensions of the midvein bundle (length, width, number of vessels and average diameter of xylem vessel) and dimensions of the lamina (lamina thickness, palisade thickness and spongy tissue thickness)\} as compared to the other water irrigation levels (45 and $25 \%$ of WHC ) In addition, the high drought stress level ( $25 \%$ of WHC) markedly decreased all the previous mentioned parameters of leaf blade. The present results were in agreement with earlier findings reported by (Khodos et al., 1976), Abou-Bakr et al. (1998) and Utrillas and 
Alegre (1997) in Cynodon dactylon plants. They found that water stress decreased both mesophyll tissue and bundle sheath cell areas during the experimental period. Yang et al. (2007) indicated that under water stress condition, xylem vessel diameter decreased as compared to the control in winter wheat plants. Desoky et al. (2013) reported that drought stress markedly decreased leaf blade thickness in wheat plants. They added that this reduction was due to the decrease in thickness of mesophell tissue. Therefore, it could be concluded that drought stress may have an inhibitor effect on the activity of the various initial cells forming leaf blade which affected cell division and enlargement. Generally, the high level of drought stress caused a reduction in the conductive tissues of wheat plant. The decrease in mesophyll tissue, xylem and phloem leads to a slow rate in the translocation of photoassimlates. Furthermore, the decreases in the diameter of vascular bundle in the leaf blade resulted in lowering the accumulation of necessary water required for photosynthesis according to Khafagy et al. (2009) on sweet pepper plant. It is clear from the results that the anatomical parameters of leaf blade were reduced under water deficit conditions. Mohamed (1996) and Mohamed et al. (2001) reported that water deficit triggers a change in hormonal balance, including an increase in leaf ABA (abscisic acid) and/or a decline in cytokinins. The increase in leaf ABA reduces cell wall extensibility and therefore causes a decline in cell elongation. Jia et al. (2001) suggested that the initiation of water deficit induced ABA accumulation was in fact brought about by weight loss of the leaf tissues as reflected by changes of cellular volume, rather than by water parameters. Tayler et al. (2005) discussed the highest $A B A$ contents might be related to the damage in the photosynthetic tissue of young tillers under water stress and to the availability of xanthophylls precursors for $A B A$, Cytosol ABA increases during water stress as a result of synthesis in the leaf, redistribution within mesophyll cells, import from the roots and recirculation from other leaves.

Table1: Effect of irrigation water levels on counts and measurements of certain histological features in transverse sections through the leaf blade of the fourth upper on Plectranthus amboinicus plant main stem during the second growing season 2015

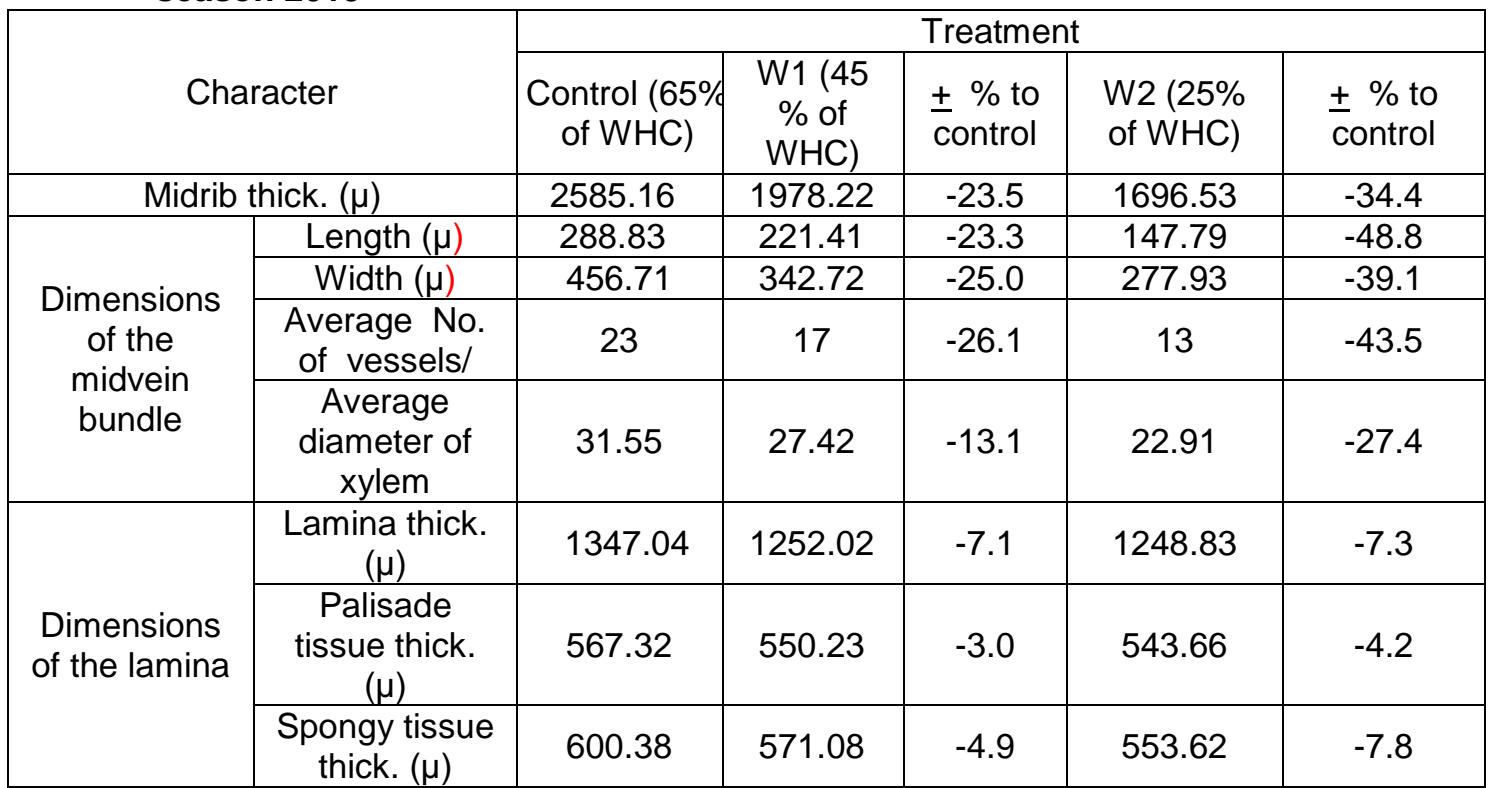

App: WHC (water holding capacity) W (water sress) control (65\% of WHC plants received adequate water), $\mathrm{W} 1(45 \%$ of $\mathrm{WHC})$ and $\mathrm{W} 2(25 \%$ of $\mathrm{WHC})$ 

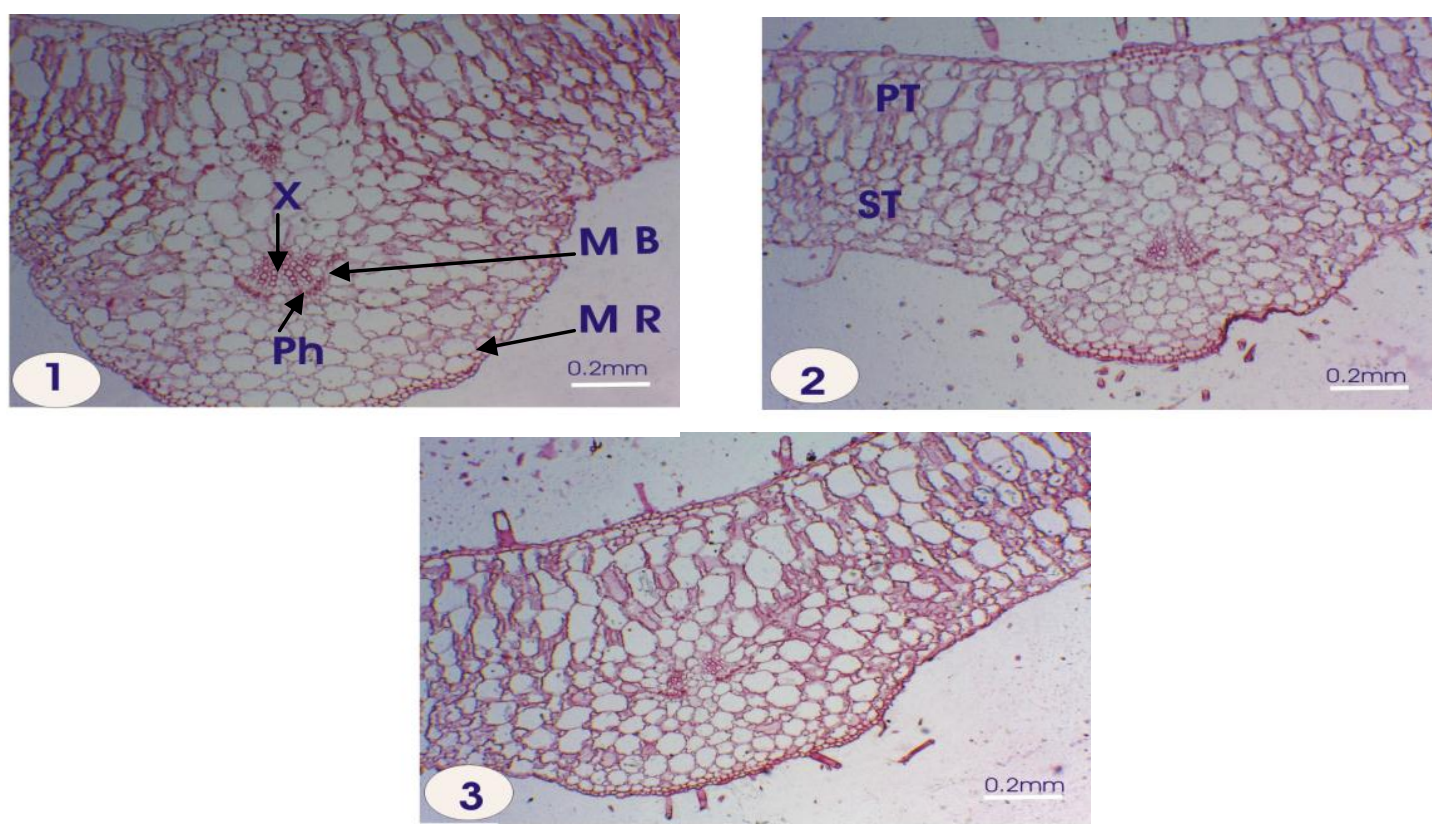

Fig. 1: Transverse sections of leaf blade of the fourth upper from the Plectranthus amboinicus plant main stem showing the effect of irrigation water levels on certain histological features during the second growing season 2015 (Scale bars $0.2 \mathrm{~mm})$

1: Control ( $65 \%$ of water holding capacity (WHC) plants received adequate water)

2: $45 \%$ of (WHC)

3: $25 \% \%$ of (WHC)

Details: PT, palisade tissue; ST, spongy tissue; MR, midrib region; MB, midvein bundle; Ph, phloem and $\mathrm{X}$, xylem

\section{Stem Structure}

The present observations represent the effect of irrigation water rates $(65,45$ and $25 \%$ of WHC) on the internal structure of the stem (Table 2 and Fig. 2). The data observation in Table 2 as for the effect of water irrigation rate $(45 \%$ of $\mathrm{WHC})$ decreased the stem dimensions (stem diameter, cortex thickness, vascular cylinder thickness, fiber strands thickness, phloem zone thickness, xylem zone thickness, average No. of xylem vessels/ vascular cylinder, diameter of xylem vessel and pith diameter) as compared to the control plants (65\% of WHC). In addition, the high drought stress level (25\% of WHC) markedly decreased all the previous mentioned parameters of stem. The diameter of the whole section of stem decreased from $5479.44 \mu$ for $65 \%$ of WHC to $3668.73 \mu$ for $25 \%$ of WHC. This reduction was accompanied by decrease in aforementioned characters. It is obvious, the high drought stress level (25\% of WHC) decreased stem dimension especially in stem diameter, cortex thickness, vascular cylinder thickness, average No. of xylem vessels/ vascular cylinder and pith diameter, and this occurred with the appearance of highly xylem fibers. The obtained results are in a good line with those previously recorded by Mohamed et al. (2001) on roselle plant, they reported that water deficit triggers a change in hormonal balance, including an increased ABA leaf (abscisic acid) and/or decline cytokinins. It was also agreed with Anwar (2005) on potato plant and Saad ElDeen (2006) on sesame plant. Drought usually induces the accumulation of reactive oxygen species (ROS), which cause oxidative damage to plants (Papadakis and Angelakis, 2005). 
Table 2: Effect of irrigation water levels on counts and measurements of certain histological features in transverse sections through the middle part of the fourth upper internode of Plectranthus amboinicus plant main stem during the second growing season 2015

\begin{tabular}{|c|c|c|c|c|c|}
\hline \multirow[b]{2}{*}{ Character } & \multicolumn{5}{|c|}{ Treatment } \\
\hline & $\begin{array}{l}\text { Control } \\
\text { (65\% of } \\
\text { WHC) }\end{array}$ & $\begin{array}{l}\text { W1 }(45 \% \\
\text { of WHC) }\end{array}$ & $\begin{array}{l} \pm \% \text { to } \\
\text { control }\end{array}$ & $\begin{array}{l}\text { W2 }(25 \% \\
\text { of WHC) }\end{array}$ & \pm control \\
\hline Stem diameter $(\mu)$ & 5479.44 & 4468.92 & -18.4 & 3668.73 & -33.1 \\
\hline Cortex thick. $(\mu)$ & 455.59 & 382.72 & -16.0 & 285.26 & -37.4 \\
\hline Vascular cylinder thick. $(\mu)$ & 637.00 & 263.47 & -58.6 & 313.05 & -50.9 \\
\hline Fiber tissue thick. $(\mu)$ & 209.39 & 40.75 & -80.5 & 49.77 & -76.2 \\
\hline Phloem zone thick. $(\mu)$ & 73.62 & 39.81 & -45.9 & 41.69 & -43.4 \\
\hline Xylem zone thick. $(\mu)$ & 353.99 & 182.91 & -48.3 & 227.23 & -35.8 \\
\hline Pith diameter $(\mu)$ & 4353.62 & 3797.93 & -12.8 & 3052.39 & -29.9 \\
\hline $\begin{array}{l}\text { Average No. of xylem } \\
\text { vessels/ vascular cylinder }\end{array}$ & 124 & 72 & -41.9 & 34 & -72.6 \\
\hline $\begin{array}{l}\text { Average diameter of xylem } \\
\text { vessel }(\mu)\end{array}$ & 62.91 & 53.15 & -15.5 & 53.52 & -14.9 \\
\hline
\end{tabular}

App: WHC (water holding capacity) W (water sress) control (65\% of WHC plants received adequate water), $\mathrm{W} 1(45 \%$ of $\mathrm{WHC})$ and $\mathrm{W} 2(25 \%$ of $\mathrm{WHC})$
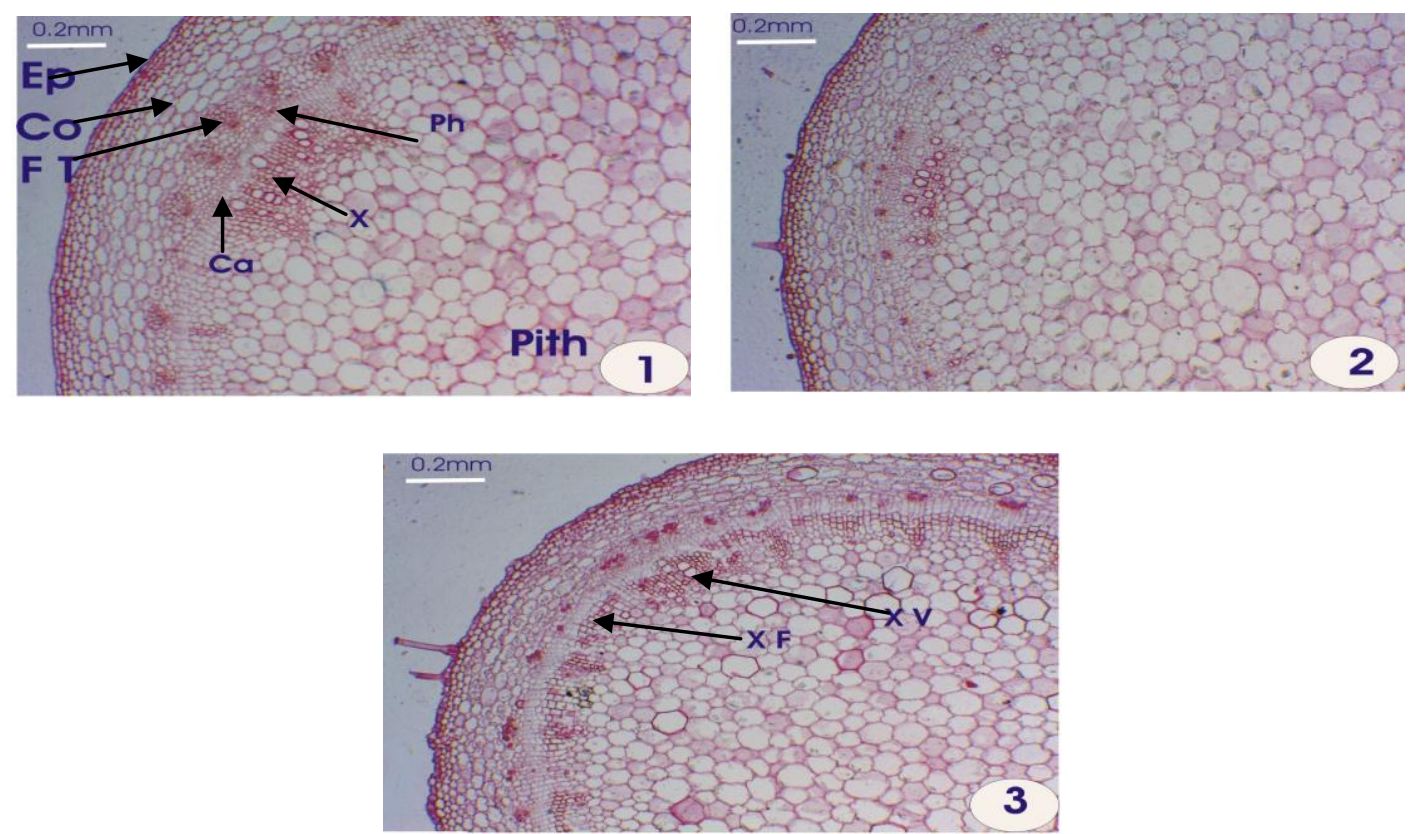

Fig. 2: Transverse sections through the middle part of the fourth upper internode from the Plectranthus amboinicus plant main stem showing the effect of irrigation water levels on certain histological features during the second growing season 2015 (Scale bars $0.2 \mathrm{~mm}$ )

1: Control (65\% of water holding capacity (WHC) plants received adequate water)

2: $45 \%$ of $(\mathrm{WHC})$

3: $25 \% \%$ of $(\mathrm{WHC})$

Details: Ep, epidermis; Co, cotex; FT, fibers tissue; Ph, phloem; Ca, cambium; $\mathrm{X}$, xylem; XV, xylem vessels; and XF, xylem fibers 


\section{Salinity stress experiment: Leaf structure}

The present observations in Table 3 and Fig. 3 represent the effect of salinity on the internal structure of the leaf blade through the midrib region as well as lamina, indicated that increasing salinity levels decreased the thickness of midrib region, due to the decrease in dimensions of the vascular bundle and parenchyma tissue. In addition, the salinity decreased lamina thickness. This reduction was accompanied by decreasing in both palisade and spongy tissues thickness, it could be concluded that salinity may have an inhibition effect on the activity of the various initial cells forming the leaf blade with regard to cell division and enlargement. It could be concluded that the high level of salinity ECw (11.7 $\left.\mathrm{dSm}^{-1}\right)$ caused destroy on almost contents of vascular bundle in midrib region. The decrease in leaf blade anatomical characters (midrib thickness, dimensions of the vascular bundle, average number of xylem vessel, average diameter of xylem vessel, blade thickness, palisade tissue thickness and spongy tissue thickness) leads to a slow rate in the accumulation of necessary water required for photosynthesis. The inhibition effect of high salinity level on leaf structure may be due to the inhibition of growth vascular elements (Rashid et al. 2004) and/or correlation with an inhibition of the procambial activity which form, primary vascular tissues and/or decrease in the number and size of mesophyll cells. These obtained results are almost in harmony with those obtained Khafagy et al. (2009) and Gadalla (2009) reported that the leaf blade anatomical characters decreased with increasing salinity levels.

\section{Stem structure}

Data presented in Table (4) and Figure (4) indicated that, increasing salinity levels markedly reduced most of stem anatomical characters, such as, diameter of the whole section, vascular cylinder thickness, fibers tissue thickness, phloem thickness, xylem thickness, average number of xylem vessel, average diameter of xylem vessel and pith thickness, meanwhile thickness of cortex was increased. The reduction in stem diameter was accompanied by decrease in both vascular cylinder and pith diameter. It was found that high quantities of xylem fibers in control plants were obtained and low xylem fibers was observed with low salinity level ECw (3.9 dSm$\left.{ }^{-1}\right)$, whereas, moderate and high salinity levels ECw (7.8 and $11.7 \mathrm{dSm}^{-1}$ ) led to absence of it. A reduction in stem diameter may be due to reduction in vascular tissue resulted from inhibition of cambial cell activity and/or reduced DNA content resulted in reduced cell division and expansion (Wignarajah et al., 1975). This result are in agreement with those reported by El- Hadidi et al. (2007) who reported that stem diameter, number of vascular bundles, thickness of both xylem and phloem tissues, were decreased with increasing salinity levels, meanwhile thickness of cortex was increased.

\section{Conclusion}

It could be concluded from the previous results that, irrigation of Indian borage plants with $65 \%$ of WHC was the superior treatment for anatomical traits as compared to $45 \%$ or $25 \% \mathrm{WHC}$, on the other side, the low level of salinity ECw $\left(3.9 \mathrm{dSm}^{-1}\right)$ had no deleterious effects on anatomical traits, while moderate and high salinity levels ECw (7.8 and $11.7 \mathrm{dSm}^{-1}$ ) caused negative effects on anatomical traits. 
Drought and salt stress induced anatomical changes in leaves and .............

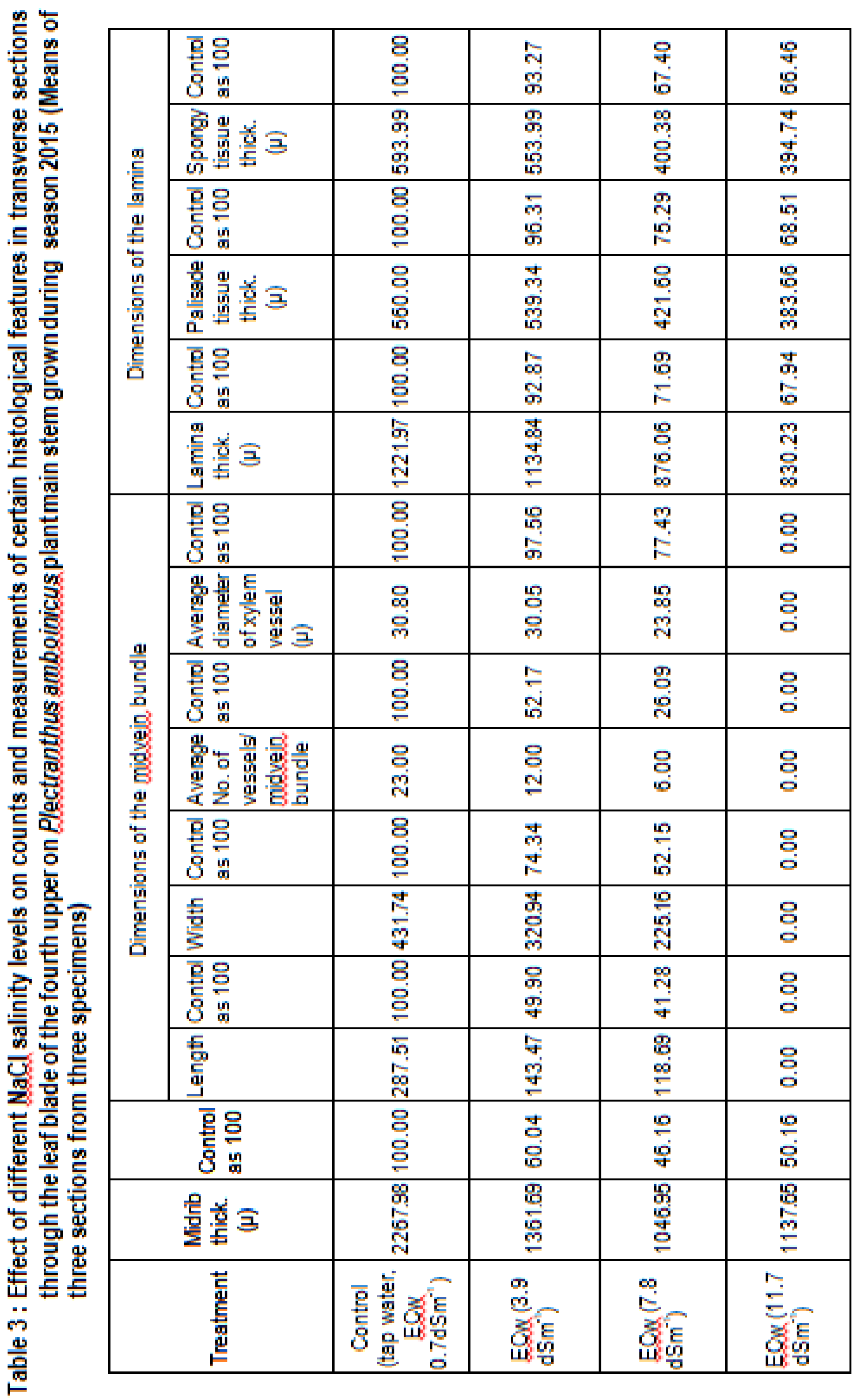



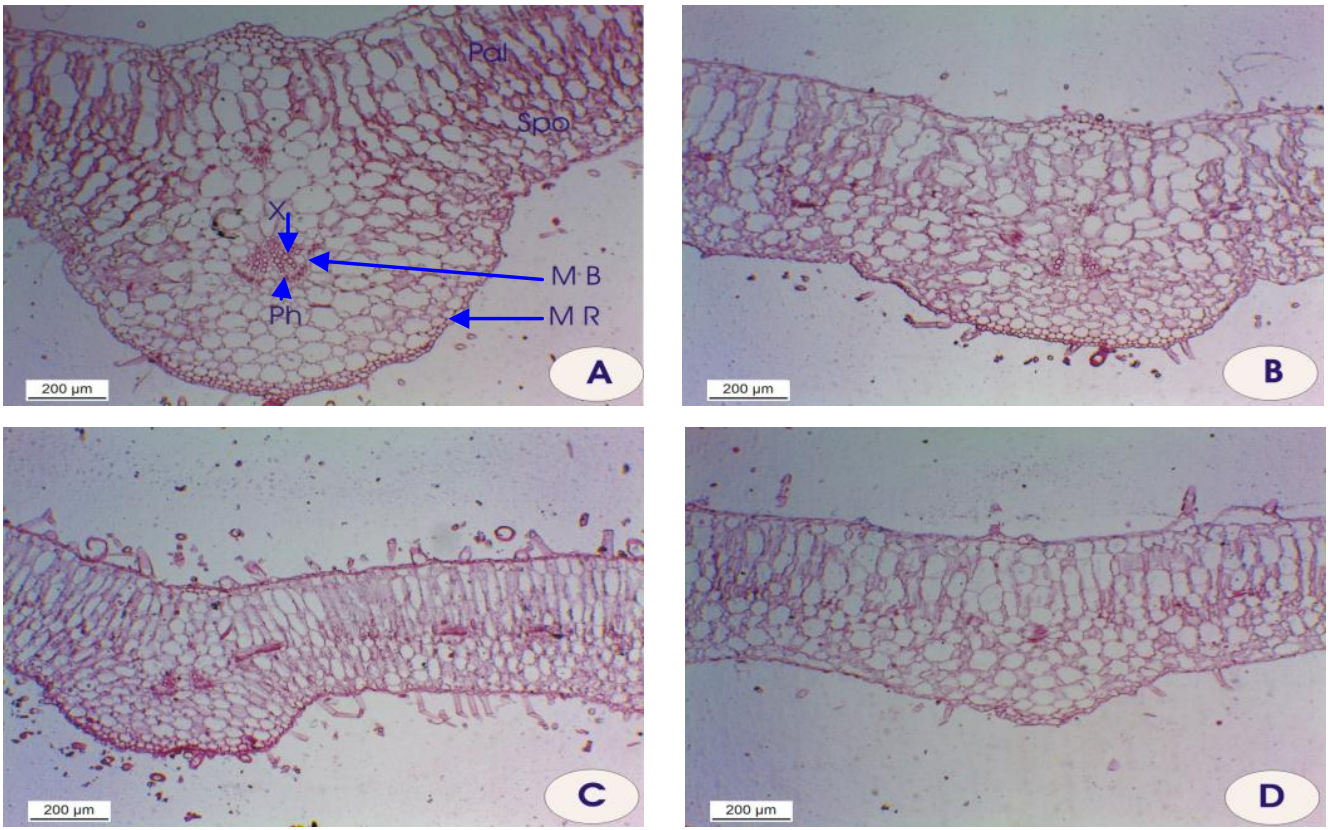

Fig. 3: Transverse sections of Plectranthus amboinicus leaf blade of the fourth upper from the main stem showing the effect of $\mathrm{NaCL}$ salinity on certain histological features during the second growing season 2015 (Scale bars $0.2 \mathrm{~mm}$ )
A: Control (tap water, ECw $0.7 \mathrm{dSm}^{-1}$ ))
B: ECw $\left(3.9 \mathrm{dSm}^{-1}\right)$

C: $\operatorname{ECw}\left(7.8 \mathrm{dSm}^{-1}\right)$

D: ECw $\left(11.7 \mathrm{dSm}^{-1}\right)$

Details: Pal, palisade tissue; Spo, spongy tissue; Mr, midrib region Mb, midvein bundle; $\mathrm{Ph}$, phloem and $\mathrm{X}$, xylem
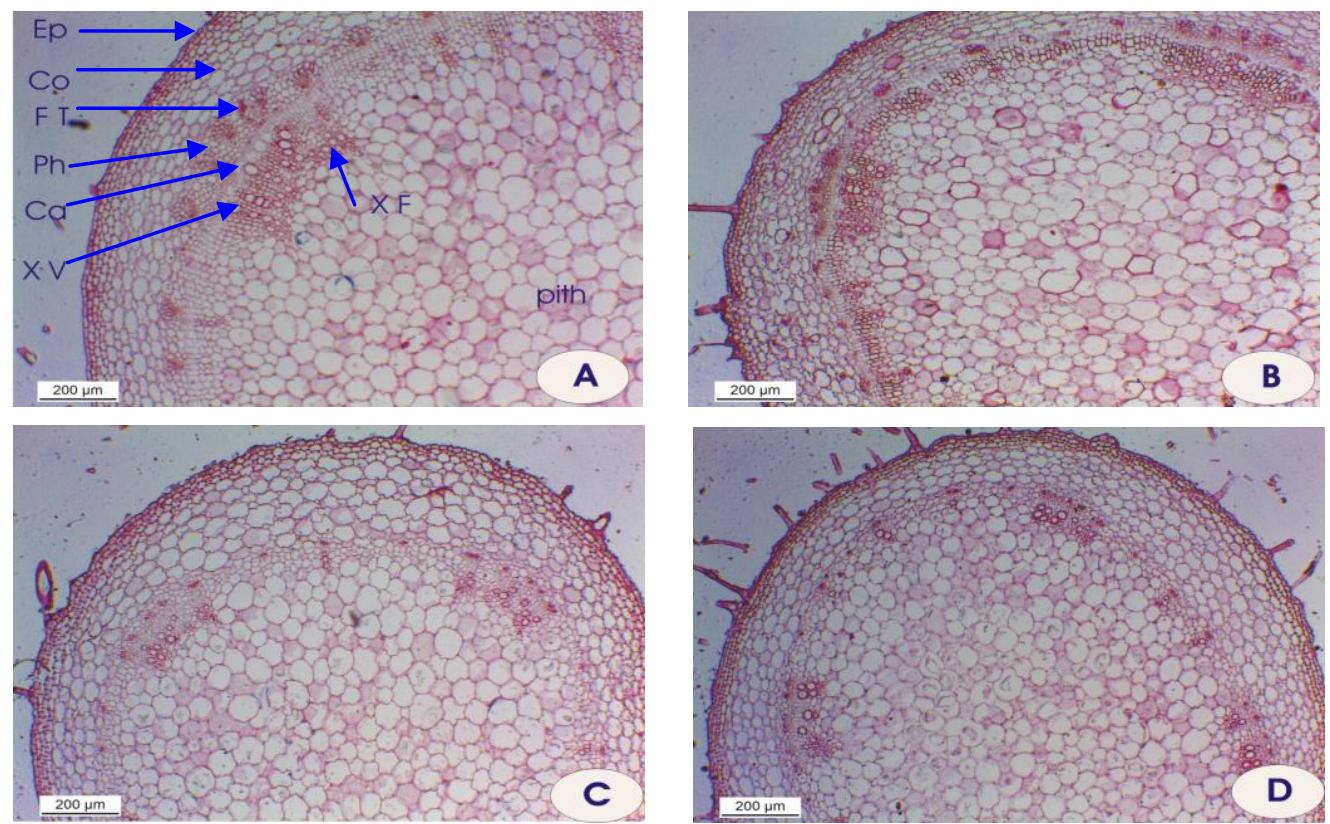

Fig. 4: Transverse sections through the middle part of the fourth upper internode from the main stem of Plectranthus amboinicus plant showing the effect of $\mathrm{NaCL}$ salinity on certain histological features during the second growing season 2015 (Scale bars $0.2 \mathrm{~mm}$ )
A: Control (tap water, ECw $0.7 \mathrm{dSm}^{-1}$ )
B: $\operatorname{ECW}\left(3.9 \mathrm{dSm}^{-1}\right)$
C: $\operatorname{ECw}\left(7.8 \mathrm{dSm}^{-1}\right)$
D: ECw $\left(11.7 \mathrm{dSm}^{-1}\right)$

Details: Ep, epidermis; Co, cotex; FT, fibers tissue; Ph, phloem; Ca, cambium; XV, xylem vessels; and XF xylem fibers 
Drought and salt stress induced anatomical changes in leaves and ............

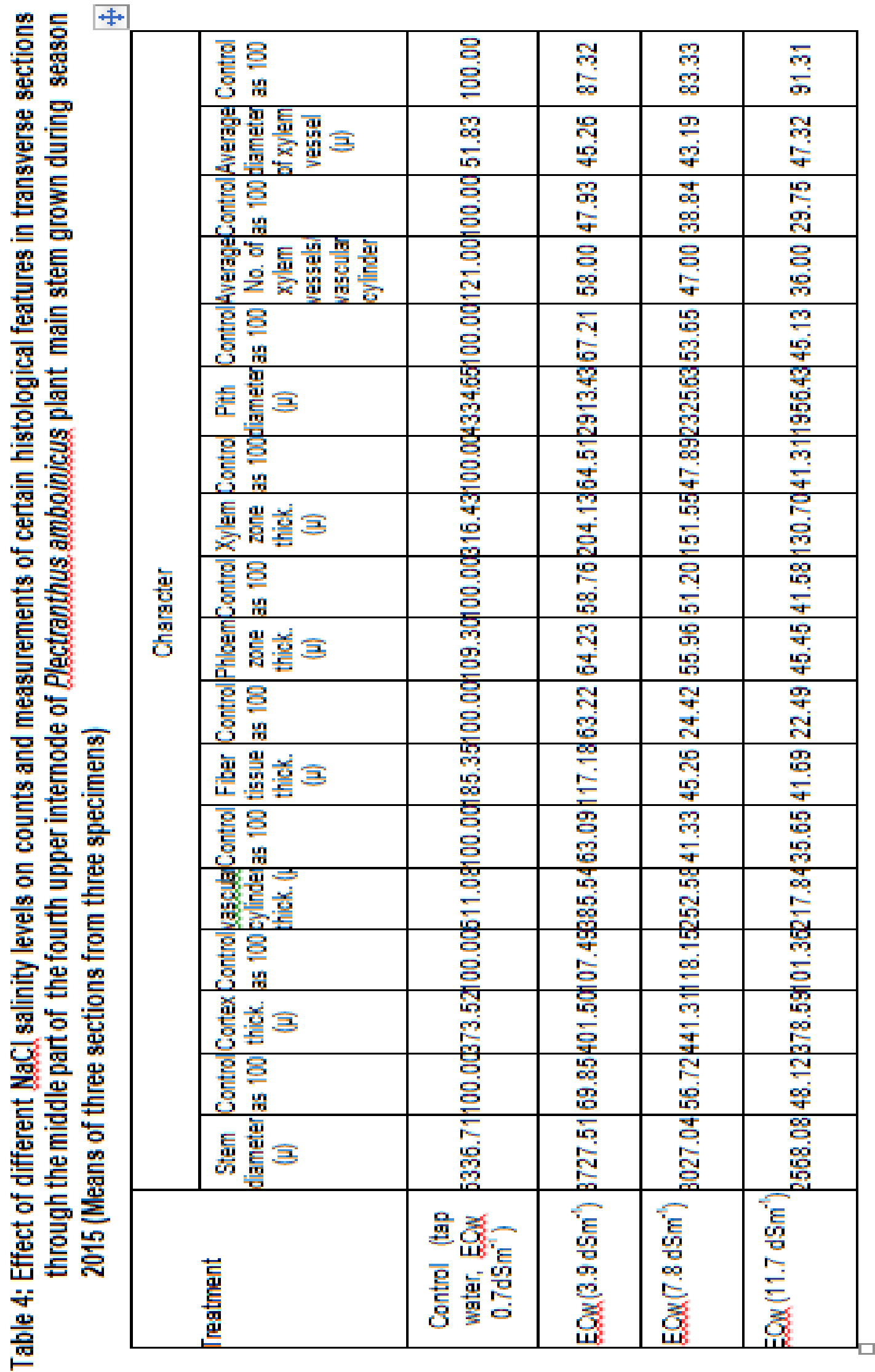




\section{REFERENCES}

Abou-Bakr, Z. Y. M., A. E. M. Hegazi, M. A. Naim and A. A. M. Khalfallah (1998). The role played by water stress and antitranspirant on water relations, stomatal regulation and anatomical character of wheat. Desert Institute Bulletin Egypt. 48 (2): 227-257.

Anwar, R.S. (2005). Response of potato crop to biofertilizers, irrigation and antitranspiration under sandy soil conditions. Ph.D. Thesis, Fac. Agric., Zagazig Univ., Egypt. pp: 75-93.

Desoky, E. M., G.S.A. Eisa, N. M. ElSarkassy and M. R. A. Tohamy (2013). Effect of some antitranspirant products on growth, yield and anatomical structure of wheat plant leaf (Triticum aestivum L.) under water stress conditions. Zagazig J. Agric. Res., 40 (2): 223-237.

El-Banna, M. N., M. A. A. Nassar, M. A. Moustafa and S. H. Abd-Allah (2002). Evaluation of some wheat genotypes under drought conditions in Nubaria region. Jr. of advances in Agric. Res., 7 (2): 349-366.

El- Hadidi, M., A.M. Abo-El-Kheer, M.T. Sakr and S. Farouk (2007). Structural and physiological studies and oil constituents of canola plants under salinity condition: 4- growth, yield and its components as well as stem structure. African Crop Science Conference Proceedings. (8): 1679-1684.

El -Tayeb, M.A. and Naglaa L. Ahmed (2010). Response of Wheat Cultivars to Drought and Salicylic Acid. AmericanEurasian Journal of Agronomy, 3 (1): 01 07.

Gadalla, S.F. (2009). The role of antoxidants in inducing wheat flag leaf osmotic adjustment under salinity stress. J. Agric. Sci. Mansoura Univ., 34 (11) 10663-10685.

Greetha, A., M. K. Swamy and U. R. Sinniah (2016). Plectranthus amboinicus (lour.) spreng: botanical, phytochemical, pharmacological and nutritional significance Molecules. 21, 369: 1-26.
Jia, W., J. Zhang and J. Liang (2001). Initiation and regulation of water deficitinduced abscisic acid accumulation in maize leaves and roots: Cellular volume and water relation. J. Exp. Bot., 52: 295300.

Khafagy, M.A., A.A. Arafa and M.F. ElBanna (2009). Glycinebetaine and ascorbic acid can alleviate the harmful effects of $\mathrm{NaCL}$ salinity in sweet pepper. Australian j. Crop Sci. 3 (5): 257-267.

Khodos, V. M., I. G. Shmat'ko and P. V. Vaida (1976). Synthesis of sugars and formation of cell walls and elements of the vascular system of wheat leaves under different regimes of water supply. Dopovidi Akademii Nauk Ukrains'koi RSR, B. (2): 172-175.

Lukhoba, C.W., M.S.J. Simmonds and A.J. Paton (2006). Plectranthus: A review of ethnobotanical uses. J. Ethnopharmacol.103, 1-24. [CrossRef] [PubMed]

Mitsuya, S., Y. Takeoka and H. Miyake (2000). Effect of sodium chloride on foliar ulrastructure of sweet potato (Ipomoea batatas Lamb.) plantlets grown under light and dark conditions in vitro. J Plant Physiol 157:661-667.

Mohamed, S.A. (1996). Influence of some environmental treatments on the growth and yield of cassava (Manihot esculenta Crantz.). Ph. D. Thesis, Fac. Agric., Fayoum Univ., Cairo, Egypt.

Mohamed, S.A., M.A. El-Yazal, R.A. Medani and R.A. Agamy (2001). Effect of nitrogen and some micronutrient fertilizers under different irrigation intervals on growth, yield and some chemical constituents of rosella (Hibiscus sabdariffa L.) plant grown in calcareous soil. Fayoum J. Agric., Res. and Develop., 15 (2): 30-49.

Papadakis, A. K. and K.A. R. Angelakis (2005). Polyamines inhibit NADPH oxidase mediated superoxides generation and putrescine prevents programmed cell death syndrome induced by the polyamine oxidase 
generated hydrogen peroxide. Planta, 220: 826-837.

Rahman, M.S., T. Matsumuro, H. Miyake and Y. Takeoka (2000). Salinity-induced ulrastructural alternation in leaf cells of rice (Oryza sativa L.). Plant Prod. Sci. 3: 422-429.

Rashid, P, J.L. Karmoker, S. Chakrabortty and B.C. Sarker (2004). The effect of salinity on ion accumulation and anatomical attributes in mungbean (Phaseolus radiatus L. cv. BARI-3) seedling. Inter. J. Agric and Biol. 6: 495498.

Roshan, P., M. Naveen, P.S. Manjul, A. Gulzar, S. Anita and S. Sudarshan (2010). Plectranthus amboinicus (Lour) Spreng: An overview. Pharm. Res. 4, 115.

Saad El-Deen, A. M. (2006). Botanical studies on sesame plants (Sesamum indicum L.) grown under newly reclaimed soil as affected by irrigation intervals and hill spacing. The Second Conference on Farm Integrated Pest Management, 1618 January, pp 84-99. Fac. Agric., Fayoum Univ.

Swamy, M.K. and U.R. Sinniah (2015). A comprehensive review on the phytochemical constituents and pharmacological activities of Pogostemon cablin Benth.: An aromatic medicinal plant of industrial importance. Molecules. 20, 8521-8547.

Tayler, I.B., T. Sonneveld, T.D.H. Bugg and A.J. Thompson (2005). Regulation and manipulation of the biosynthesis of Abscisic acid including the supply of xanthophylls precursors. J. Plant Growth Regul., 24:253-273.

Utrillas, M. J. and L. Alegre (1997). Impact of water stress on leaf anatomy and ultrastructure in Cynodon dactylon (L.) Pers. under natural conditions. Int. J. Plant Sci., 158 (3): 313-324.

Wignarajah, D., H. Jennings and J.F. Handley (1975). The effect of salinity on growth of Phaseolus vulgaris L. 1Anatomical changes in the first trifoliate leaf. Ann. Bot. 39, 1029-1038.

Willey, R.L. (1971). Microtechnique. A Laboratory Guide. Mac Millan Publishing Co. Inc. New York, U.S.A.

Yang, X., S. Zhang, X. F. Liu and Z. X. Mu (2007). Relationship between roots hydraulic conductivity and root anatomy of winter wheat ( $T$. aestivum). $J$. of Northwest $A$ and $F$ University Natural Science Edition 35(8): 160-164.

Zhu, J.K. (2001). Plant salt tolerance. Trend Plant Sci. 6: 266-271. 
التغيرات التشريحية فى أولق وسوق نباتات السجاد الهندى نتيجة الاجهاد

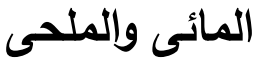

\section{جلال سرور عبد الحميذ عيسى}

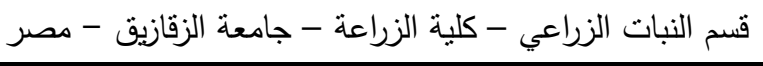

الملخص العربى

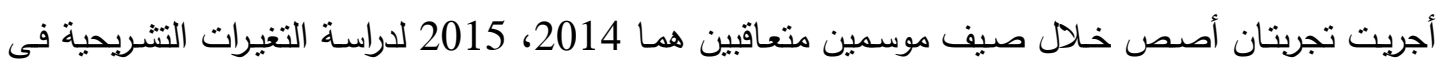

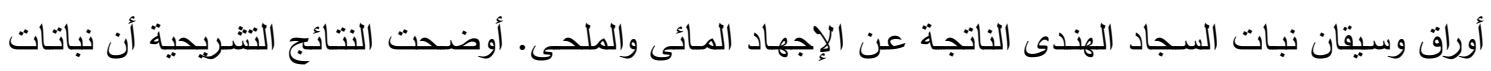

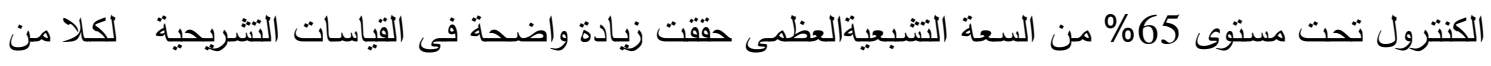

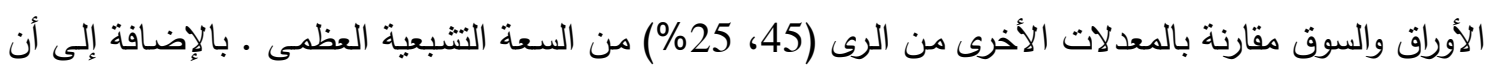

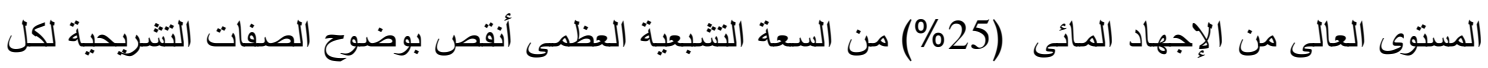

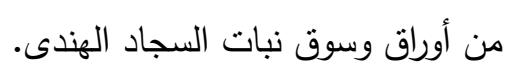

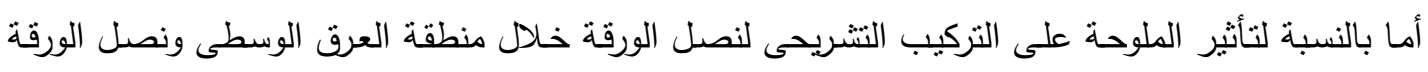

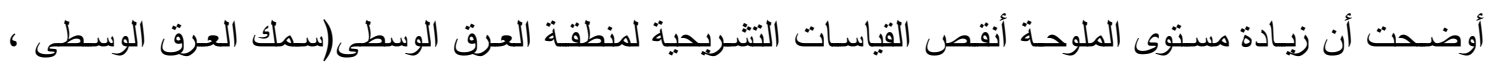

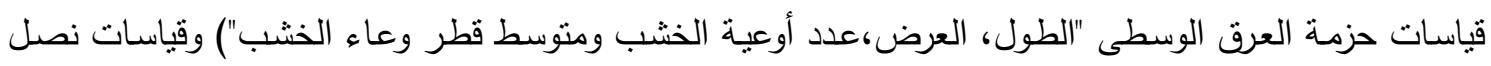

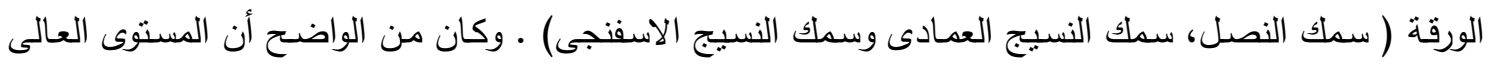

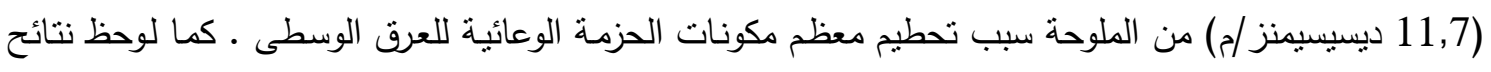

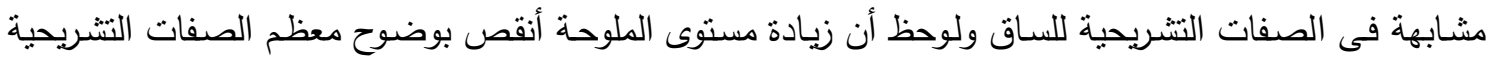

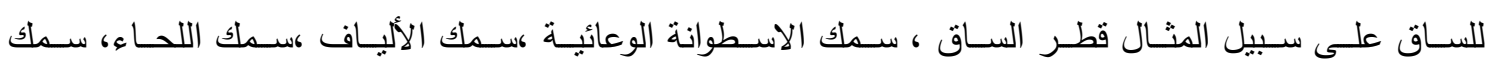

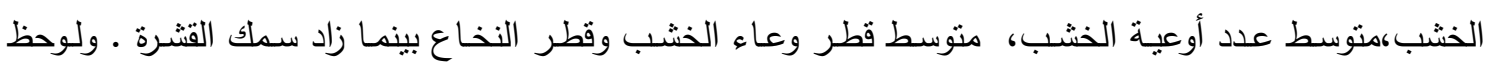

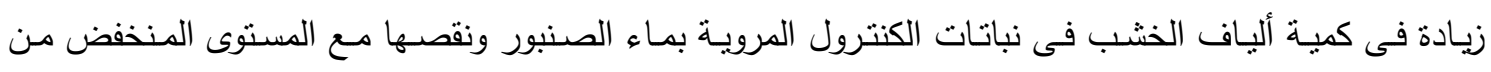

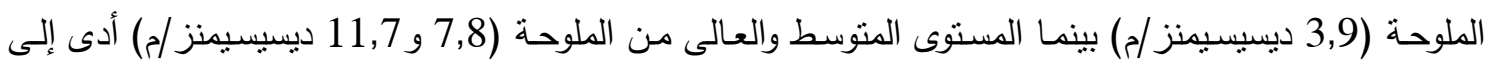
غيابها. 
Drought and salt stress induced anatomical changes in leaves and ............ 
Drought and salt stress induced anatomical changes in leaves and ............ 
